\title{
The Complete Phlogopite-Tetraferriphlogopite Series in the Catalão-I and -II Carbonatite Complexes, Brazil
}

\author{
Araújo, D.P. ${ }^{1}$, Gaspar, J.C. ${ }^{1}$ and V. K. Garg ${ }^{2}$ \\ 1. Instituto de Geociências, Universidade de Brasília, Brasília , 70910-900, Brazil. debora@guarany.cpd.unb.br \\ 2. Departamento de Física, Universidade de Brasília, Brasília, 70910-900, Brazil
}

\section{Introduction}

Phlogopite from the Catalão-I and -II Carbonatite Complexes shows a wide range in $\mathrm{Al}_{2} \mathrm{O}_{3}(0.01$ to $14.5 \% ; 0.0$ to 2.5 a.p.f.u) and $\mathrm{FeO}$ (5.0 and 32.3\%) contents and also normal and reverse pleochroism, what has suggested the occurrence of. the phlogopite-tetraferriphlogopite series (Araújo and Gaspar, 1993). Therefore, in order to verify the existence of the $\mathrm{Fe}^{3+(\mathrm{IV})} \leftrightarrow \mathrm{Al}^{3+(\mathrm{IV})}$ substitution three samples were analyzed in a Mössbauer spectrometer and the results were compared to their average chemical composition. The presence of tetrahedral ferric iron has been confirmed in phlogopite and biotite through Mössbauer spectroscopy (e.g. Dyar, 1987; Rancourt et al, 1992, Cruciani et al, 1995).

Geological Setting

The Catalão-I and -II Carbonatite Complexes are located in the southeast part of the Goiás State, central Brazil. They belong to the Cretaceous Alto Paranaíba Magmatic Province which comprises several alkaline occurrences as kimberlitic rocks (Bizzi et al, 1991; Bizzi, 1993), kamafugites (Sgarbi and Valença, 1991) and other carbonatites along a NW regional trend (AZ 125). The complexes are intruded in metasedimentary rocks (Araxá Group) of the Neoproterozoic Brasília Fold Belt which occurs in the southwestern border of the São Francisco Craton. The Catalão-I Complex is $10 \mathrm{Km}$ far away from Catalão-II. They are interpreted as cogenetic bodies comprising an ultramafic phase represented by dunite and clinopyroxenite and several carbonatite phases. The carbonatites had interacted with the primary ultramafic rocks forming carbonate-, phlogopite- and clinopyroxenebearing rocks. Phoscorites also occur and are associated to the carbonatite. In the Catalão-I Complex a breccia with a phlogopite- and olivine- rich matrix cut the former rocks and contains fragments of the rock intrusion.

\section{Chemical results}

The phlogopites were analyzed in a CAMECA SX-50 microprobe (15kv and $25 \mathrm{nA})$ at the University of Brasília. 96 analysis represent phlogopites from the clinopyroxenite, carbonatite, phoscorite, phlogopitite, and the breccia. The chemical analysis were normalized to 22 oxygen and the tetrahedral site ( $\mathrm{T}$ site) is fulfilled with $\mathrm{Fe}^{3+}$ until the sum of $\mathrm{Si}, \mathrm{Al}$ and $\mathrm{Fe}^{3+}$ equals 8.0 p.f.u., yielding the stequiometric $\mathrm{Fe}^{3+(\mathrm{IV})}\left(\mathrm{Fe}^{3+(\mathrm{IV})^{*}}\right.$; in Table 1). $\mathrm{Fe}^{3+}$ does not enter in the octahedral site. The plots of $\mathrm{Fe}^{3+(\mathrm{IV})^{*}}$ versus $\mathrm{Al}^{3+(\mathrm{IV})}$ and $\mathrm{Si}^{4+(\mathrm{IV})}$ versus $\mathrm{Al}^{3+(\mathrm{IV})}$ presented in figures 1 and 2 clearly exhibit a possible phlogopite-tetraferriphlogopite series where the normal and reverse crystals are shown. The phlogopites can be divided in two groups according to their pleochroism and chemical composition: (1) high Al-, Ti- and low Si-, $\mathrm{Mg}$ - and $\mathrm{Fe}_{\mathrm{t}}$ - phlogopites with normal pleochroism, and (2) high $\mathrm{Fe}_{\mathrm{t}}-$ and $\mathrm{Si}$ - and low $\mathrm{Al}$ - and $\mathrm{Ti}$ - tetraferriphlogopites with reverse pleochroism. Si plays an important role in cationic substitutions of the normal phlogopites. As shown in Figure 2 there is a clear break in the series for $\mathrm{Al}^{\mathrm{V}}>1.5$ a.p.f.u., coincident with pleochroism change, when it is observed an inverse correlation between $\mathrm{Si}^{\mathrm{IV}}$ and $\mathrm{Al}^{\mathrm{IV}}$. The high $\mathrm{Al}^{\mathrm{IV}}$ content is accompanied by high $\mathrm{Ti}^{\mathrm{VI}}$ and low $\mathrm{Mg}^{\mathrm{VI}}$. The most important coupled substitution for the high $\mathrm{Al}$ members of the series could be $\mathrm{Ti}^{4+(\mathrm{VI})}+$ $2 \mathrm{Al}^{3+(\mathrm{IV})} \leftrightarrow \mathrm{Mg}^{2+(\mathrm{Vn})}+2 \mathrm{Si}^{4+(\mathrm{IV})}$. Conversely, the reverse tetraferriphlogopites show a smooth inverse correlation between $\mathrm{Si}^{\mathrm{IV}}$ and $\mathrm{Al}^{\mathrm{IV}}$ but $\mathrm{Fe}^{\mathrm{IV}}$ and $\mathrm{Al}^{\mathrm{IV}}$ are strongly antipathetic, which does not happen in normal or high $\mathrm{Al}$ - phlogopites (Figure 1). $\mathrm{The}^{\mathrm{Fe}}{ }^{2+(\mathrm{VI})}-\mathrm{Mg}^{2+(\mathrm{VI})}$ substitution is more pronounced in 
tetraferriphlogopites. The coupled substitution $\mathrm{Fe}^{3+(\mathrm{IV})}+\mathrm{Fe}^{2+(\mathrm{IV})} \leftrightarrow \mathrm{Mg}^{2+(\mathrm{VI})}+\mathrm{Al}^{3+(\mathrm{IV})}$ is proposed for the high $\mathrm{Fe}^{3+\left(\mathrm{IN}^{*}\right)}$ series members (Araújo, 1996).

\section{Mössbauer results}

Three phlogopite samples were analyzed in the Mössbauer spectrometer at the University of Espirito Santo, Brazil. The samples were submitted to $\gamma$-Ray absorption using a ${ }^{57} \mathrm{CO} / \mathrm{Rh}$ source and pattern transmission geometry. The $\mathrm{Fe}^{2+} / \mathrm{Fe}^{3+}$ Mössbauer ratio is shown in Table 1.

Comparison between chemical and Mossbäuer results

The Mossbäuer $\mathrm{Fe}^{2+} / \mathrm{Fe}^{3+}$ ratio was applied in the phlogopite chemical normalization in order to verify the iron distribution in the tetrahedral and octahedral sites. Table 1 presents the average chemical composition for each sample, their $\mathrm{Fe}^{2+} / \mathrm{Fe}^{3+}$ ratio, and the normalization used as following: (1) determination of $\mathrm{Fe}^{2+}$ and $\mathrm{Fe}^{3+}$ amount according to the Mossbäuer $\mathrm{Fe}^{2+} / \mathrm{Fe}^{3+}$ ratio for each sample; (2) fulfillment of the $\mathrm{T}$ site with $\mathrm{Fe}^{3+}$ until 8.0 a.p.f.u.. (3) fulfillment of the $\mathrm{O}$ site with the remaining $\mathrm{Fe}^{3+}$. The $\mathrm{O}$ site became slightly vacant.

\section{Discussion}

The detection of $\mathrm{Fe}^{3+}$ in tetrahedral sites in the phlogopites of Catalão-I and -II through Mössbauer analysis confirms the existence of the tetraferriphlogopite member in these complexes. Considering also the large range of $\mathrm{Al}$ and $\mathrm{Fe}_{t}$ and due to the $\mathrm{Al}^{\mathrm{IV}}$ variation from 0.0 to 2.5 a.p.f.u. (Figure 1) we report the first occurrence of a complete phlogopite-tetraferriphlogopite series.

\section{References}

Araújo, D.P. and Gaspar, J.C., 1993, $\mathrm{Fe}^{3+}$ in the tetrahedral site of the Catalão-I Alkaline Complex. IV Cong. Bras. Geoq. Ex. Abs.:62-3 (in portuguese).

Araújo, D.P. ,Gaspar, J.C., Garg, V.K., and Souza Jr. P.A., 1996, Mössbauer determination in a single tetraferriphlogopite crystal of the Catalão-II Carbonatite Complex. XXXVIII Cong. Bras. Geol. Ex. Abs.: 22-5 (in portuguese).

Araújo, D.P., 1996, Metasomatism in the Catalão-I Carbonatite Complex: Implication to the carbonatitic magma composition and to the upper mantle carbonatite metasomatism. MsC Thesis, University of Brasília (in portuguese).

Bizzi, L.A., 1993, mesozoic alkaline volcanism and mantle evolution of the southwestern São Francisco Craton, Brazil. Ph.D. Thesis, University of Cape Town.

Bizzi, L.A.; Smith, C.B.; Meyer, H.O.A.; Arstrong, R. e De Wit, M.J. (1991) mesozoic kimberlites and related associated alkalic rocks in the south-western São Francisco Craton, Brazil: A case for local mantle reservoir and their interaction. V Int. Kimberlite Conf.(CPRM)Spec. publ. p. 1719.

Cruciani, G.; Zanazzi, P.F. e Quartieri, S., 1995, Tetrahedral ferric iron in phlogopites: XANES and Mössbauer compared to single-crystal X-ray data. Eur J Mineral, 7: 255-65.

Dyar, M.D., 1987, A review of Mössbauer data on trioctahedral micas: evidence for tetrahedral $\mathrm{Fe}^{3+}$ and cation ordering. Am Mineral, 72: 792-800.

Rancourt, D.G.; Dang, M.Z. e Lalonde, A.E., 1992, Mössbuaer spectroscopy of tetrahedral $\mathrm{Fe}^{3+}$ in trioctahedral micas. Am Mineral, 77: 34-43.

Sgarbi, P.B.A. e Valença, J.G., 1993, Kalsitic in Brazilian kamafugitic rocks. Min. Mag,57: 165-171. 


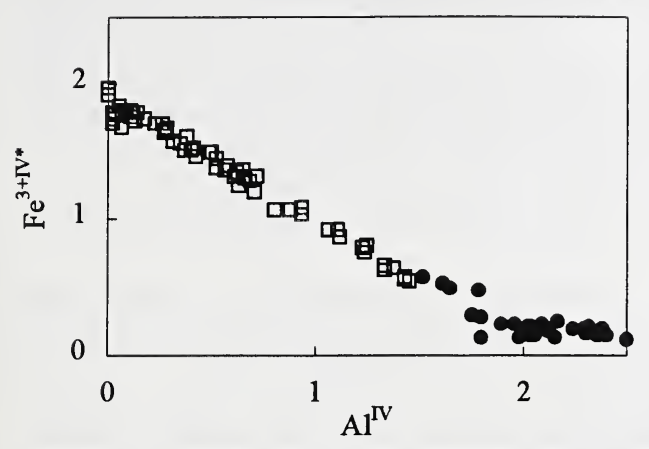

Figure $01-\mathrm{Fe}^{3+\mathrm{IV}^{*}}$ and $\mathrm{Al}^{\mathrm{IV}}$ for phlogopites from Catalão-I and -II. Open squares: reverse pleochroism; filled circles: normal pleochroism.

Table 1 - Average Chemical Composition of Phlogopite.

Normalization based on $\mathrm{Fe}^{2+} / \mathrm{Fe}^{3+}$ (see text).

\begin{tabular}{|c|c|c|c|}
\hline & $\mathbf{C 6 1}$ & $\mathbf{C 6 2}$ & S/N \\
\hline $\mathrm{SiO}_{2}$ & 38,68 & 36,85 & 37,51 \\
\hline $\mathrm{TiO}_{2}$ & 2,74 & 3,07 & 2,89 \\
\hline $\mathrm{Al}_{2} \mathrm{O}_{3}$ & 7,91 & 7,41 & 8,08 \\
\hline $\mathrm{Cr}_{2} \mathrm{O}_{3}$ & 0,01 & 0,01 & 0,02 \\
\hline $\mathrm{Fe}_{2} \mathrm{O}_{3}$ & 10,10 & 9,28 & 8,59 \\
\hline $\mathrm{FeO}$ & 14,57 & 15,85 & 15,63 \\
\hline $\mathrm{MnO}$ & 0,24 & 0,25 & 0,24 \\
\hline $\mathrm{MgO}$ & 13,19 & 11,63 & 12,34 \\
\hline $\mathrm{BaO}$ & 0,00 & 0,00 & 0,00 \\
\hline $\mathrm{CaO}$ & 0,00 & 0,00 & 0,00 \\
\hline $\mathrm{Na}_{2} \mathrm{O}$ & 0,08 & 0,06 & 0,06 \\
\hline $\mathrm{K}_{2} \mathrm{O}$ & 9,64 & 9,52 & 9,52 \\
\hline $\mathrm{H}_{2} \mathrm{O}$ & 3,70 & 3,58 & 3,62 \\
\hline $\mathrm{F}$ & 0,29 & 0,22 & 0,27 \\
\hline $\mathrm{Cl}$ & 0,01 & 0,00 & 0,01 \\
\hline $\mathrm{O}=\mathrm{F}$ & 0,12 & 0,09 & 0,11 \\
\hline $\mathrm{O}=\mathrm{Cl}$ & 0,00 & 0,00 & 0,00 \\
\hline $\mathrm{Total}$ & 101,29 & 97,81 & 98,89 \\
\hline
\end{tabular}

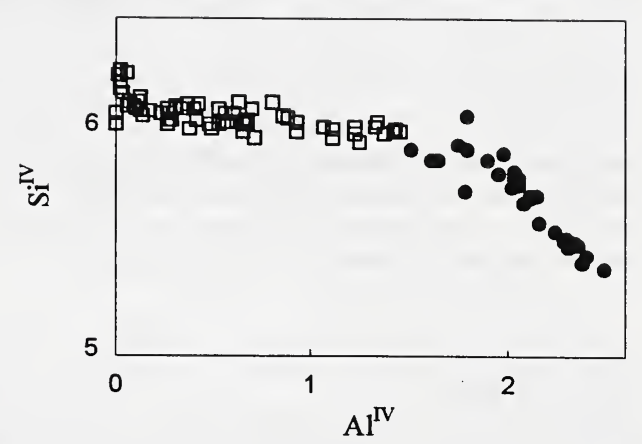

Figure $02-\mathrm{Si}^{\mathrm{IV}}$ and $\mathrm{Al}^{\mathrm{IV}}$ for phlogopites from CatalãoI and -II. Open squares: reverse pleochroism; filled circles: normal pleochroism.

\begin{tabular}{|c|c|c|c|}
\hline & C61 & C62 & $S / N$ \\
\hline$S i^{I V}$ & 6,02 & 5,99 & 5,98 \\
\hline$A !^{N}$ & 1,45 & 1,42 & 1,52 \\
\hline $\mathrm{Fe}^{3+1 V_{\star}}$ & 0,53 & 0,59 & 0,50 \\
\hline T Site & 8,00 & 8,00 & 8,00 \\
\hline $\mathrm{Al}^{\mathrm{V}}$ & 0,00 & 0,00 & 0,00 \\
\hline $\mathrm{Ti}^{\mathrm{V}}$ & 0,32 & 0,38 & 0,35 \\
\hline $\mathrm{Cr}$ & 0,00 & 0,00 & 0,00 \\
\hline $\mathrm{Fe}^{3+\mathrm{V} /}$ & 0,65 & 0,54 & 0,53 \\
\hline $\mathrm{Fe}^{2+\mathrm{V}}$ & 1,90 & 2,15 & 2,08 \\
\hline $\mathrm{Mn}^{+2}$ & 0,03 & 0,03 & 0,03 \\
\hline $\mathrm{Mg}$ & 3,06 & 2,82 & 2,93 \\
\hline O Site & 5,96 & 5,93 & 5,93 \\
\hline $\mathrm{Ba}$ & 0,00 & 0,00 & 0,00 \\
\hline $\mathrm{Ca}$ & 0,00 & 0,00 & 0,00 \\
\hline $\mathrm{Na}$ & 0,02 & 0,02 & 0,02 \\
\hline $\mathrm{K}$ & 1,91 & 1,97 & 1,94 \\
\hline A site & 1,94 & 1,99 & 1,96 \\
\hline 0 & 20,01 & 20,01 & 20,01 \\
\hline $\mathrm{OH}$ & 3,84 & 3,88 & 3,85 \\
\hline$F$ & 0,14 & 0,11 & 0,13 \\
\hline $\mathrm{Cl}$ & 0,00 & 0,00 & 0,00 \\
\hline Charge & 0,00 & 0,00 & 0,00 \\
\hline $\mathrm{Fe}^{2+} / \mathrm{Fe}^{3+} \star$ & 1.604 & 1.898 & 2.021 \\
\hline
\end{tabular}

$\mathrm{Fe}^{2+} / \mathrm{Fe}^{3+}$ * $-\mathrm{Fe}^{2+} / \mathrm{Fe}^{3+}$ Mössbauer ratio 